\title{
Senescent cancer-associated fibroblasts secrete active MMP-2 that promotes keratinocyte dis-cohesion and invasion
}

\author{
Y Hassona ${ }^{1,2}$, N Cirillo ${ }^{\star 3,4}$, K Heesom $^{5}$, E K Parkinson ${ }^{6}$ and S S Prime ${ }^{\star, 1,6}$ \\ ${ }^{1}$ Department of Oral and Dental Sciences, University of Bristol, Bristol, UK; ${ }^{2}$ Department of Dentistry, University of Jordan, \\ Amman, Jordan; ${ }^{3}$ Melbourne Dental School and Oral Health CRC, University of Melbourne, 720 Swanston Street, Carlton, Victoria \\ 3053, Australia; ${ }^{4}$ Centre for Innovation, Research, Education and Health (IRIS), Italy; ${ }^{5}$ Department of Biochemistry, University of \\ Bristol, Bristol, UK and ${ }^{6}$ Centre for Clinical and Diagnostic Oral Sciences, Institute of Dentistry, Barts and the London School of \\ Medicine and Dentistry, Queen Mary University of London, Turner Street, London E1 2AD, UK
}

Background: Previous studies have demonstrated that senescent cancer-associated fibroblasts (CAFs) derived from genetically unstable oral squamous cell carcinomas (GU-OSCC), unlike non-senescent CAFs from genetically stable carcinomas (GS-OSCC), promoted keratinocyte invasion in vitro in a paracrine manner. The mechanism by which this occurs is unclear.

Methods: Previous work to characterise the senescent-associated secretory phenotype (SASP) has used antibody arrays, technology that is limited by the availability of suitable antibodies. To extend this work in an unbiased manner, we used 2D gel electrophoresis and mass spectroscopy for protein identification. Matrix metalloproteinases (MMPs) were investigated by gelatin zymography and western blotting. Neutralising antibodies were used to block key molecules in the functional assays of keratinocyte adhesion and invasion.

Results: Among a variety of proteins that were differentially expressed between CAFs from GU-OSCC and GS-OSCC, MMP-2 was a major constituent of senescent CAF-CM derived from GU-OSCC. The presence of active MMP-2 was confirmed by gelatine zymography. MMP-2 derived from senescent CAF-CM induced keratinocyte dis-cohesion and epithelial invasion into collagen gels in a TGF- $\beta$-dependent manner.

Conclusions: Senescent CAFs from GU-OSCC promote a more aggressive oral cancer phenotype by production of active MMP-2, disruption of epithelial adhesion and induction of keratinocyte invasion.

The acknowledgement that the mesenchymal component of solid tumours has a critical role in tumour pathogenesis has led to the concept that epithelial cancers are dysfunctional tissues rather than simply an accumulation of a critical number of mutations in tumour cells (Hanahan and Weinberg, 2011). The non-malignant cells, together with the ECM, constitute the tumour stroma and pre-eminent in the stroma are cancer-associated fibroblasts (CAFs; Kalluri and Zeisberg, 2006).

A considerable body of evidence has shown that cellular senescence acts as a barrier to epithelial malignancy. In oral squamous cell carcinoma (OSCC), we and others have shown that the loss of genes such as TP53 and $p 16^{I N K 4 A}$ leads to the development of genetically unstable OSCC (GU-OSCC; Edington et al, 1995; Loughran et al, 1997; Weber et al, 1998; Hunter et al, 2006; Pickering et al, 2013; Thakker and Parkinson, unpublished observations). Not all OSCCs, however, are dysfunctional for p53, and genetically stable carcinomas (GS-OSCC) have been identified (Agrawal et al, 2011; Stransky et al, 2011; Pickering et al, 2013). Recently, we isolated CAFs from GU-OSCC and demonstrated that they had a distinct transcriptional profile that distinguished them from GS-OSCC CAFs and from normal human oral mucosal fibroblasts (NHOF; Lim et al, 2011). Further, we have shown that

*Correspondence: Professor SS Prime; E-mail: stephensprime@gmail.com or Professor N Cirillo; E-mail: Nicola.cirillo@unimelb.edu.au

Received 30 November 2013; revised 2 May 2014; accepted 26 June 2014; published online 12 August 2014

(c) 2014 Cancer Research UK. All rights reserved 0007-0920/14 
CAFs from GU-OSCC have high levels of senescence, a phenotype that promotes keratinocyte invasion in vitro relative to nonsenescent fibroblasts (Hassona et al, 2013). Similar observations have been made by others (Krtolica et al, 2001; Pazolli et al, 2009), and the pro-tumorigenic effect of senescent fibroblasts has been attributed to the secretion of a myriad of soluble factors, proteases and non-protein secretions collectively described as the senescentassociated secretory phenotype (SASP; Coppé et al, 2008; Kuilman and Peeper, 2009).

Previous work to characterise the SASP showed that the SASP was not a fixed phenotype but changed according to the fibroblast strain and culture conditions (Coppé et al, 2008). In these studies, the constituents of the SASP were quantified using antibody arrays, technology that is limited by the availability of suitable antibodies. In the present study, we sought to extend the previous work in an unbiased manner and used 2D gel electrophoresis and mass spectroscopy for protein identification. One of the proteins identified was MMP-2, an interesting finding because we had previously shown it to be a component of the conditioned medium (CM) of senescent oral fibroblasts in the premalignant condition oral submucous fibrosis (Pitiyage et al, 2011), and yet, it had not been reported as part of the SASP (Coppé et al, 2008). In the present study, we show that MMP-2 is activated in CAF-CM and causes epithelial dis-cohesion with subsequent increased invasion of keratinocytes in vitro in a TGF- $\beta$-dependent manner.

\section{MATERIALS AND METHODS}

Cell strains and culture conditions. Details of the fibroblast strains and keratinocyte cell lines have been documented previously (Lim et al, 2011; Hassona et al, 2013). Fibroblasts were derived from normal oral mucosa (NHOF1, NHOF2, NHOF6), genetically stable OSCC (GS-OSCC/BICR66F, GS-OSCC/ BICR73F, GS-OSCC/BICR59F) and genetically unstable OSCC (GU-OSCC/H357F, GU-OSCC/H314F, GU-OSCC/BICR18F, GU-OSCC/BICR3F). The keratinocyte cell line used in the adhesion and invasion assays was $\mathrm{H} 357$, because it harbours TP53 mutations (Yeudall et al, 1995), inactive $p 16^{I N K 4 A}$ (Wu et al, 1999) and is non-tumorigenic in vivo (Prime et al, 2004) and noninvasive in organotypic cultures (Lim et al, 2011).

Fibroblasts were cultured in DMEM supplemented with $10 \%$ $(\mathrm{v} / \mathrm{v})$ foetal bovine serum (FBS) and $2 \mathrm{~mm}$ L-glutamine and grown in standard conditions (humidified atmosphere of $5 \% \mathrm{CO}_{2} / 95 \%$ at $37 \mathrm{C}^{\circ}$ ); cells were examined at passages $<12$. Keratinocytes were cultured in DMEM-F12 supplemented with $10 \%$ (v/v) FBS and $0.5 \mu \mathrm{g} \mathrm{ml}^{-1}$ hydrocortisone in standard conditions. In certain experiments, $1 \times 10^{4}$ NHOF1 were seeded into $60-\mathrm{mm}$ culture dishes, grown until $60 \%$ confluent and then treated with $600 \mu \mathrm{M}$ $\mathrm{H}_{2} \mathrm{O}_{2}$ (BDH) for $2 \mathrm{~h}$ each day for 5 days. The cells recovered in fresh culture media for 5 days before analysis. The induction of senescence was confirmed by upregulation of SA $\beta$-Gal activity and p16 ${ }^{\mathrm{INK} 4 \mathrm{~A}}$, as demonstrated previously (Hassona et al, 2013).

Collection of CM. Cells were grown in $75-\mathrm{cm}$ flasks until they were $70-90 \%$ confluent, washed with serum-free media $(3 \times)$ and PBS $(3 \times)$ and then incubated in $7 \mathrm{ml}$ serum-free media for a further $48 \mathrm{~h}$. The CM was centrifuged at 2000 r.p.m. for $5 \mathrm{~min}$ to remove dead cells. The viable attached cells were trypsinised and counted; the CM was normalised to $0.5 \times 10^{6}$ fibroblasts. $\mathrm{CM}$ was stored at $-20 \mathrm{C}^{\circ}$.

Protein concentration. Fibroblast CM was centrifuged in Centricon YM-10 centrifugal concentrator units (Millipore (UK) Ltd, Feltham, Hertfordshire, UK) at $3000 \mathrm{~g}$ for $30 \mathrm{~min}$ in a MSE Mistral 2000 bench top centrifuge. The filtrate was discarded, and the process was repeated to obtain a volume of approximately $50 \mu \mathrm{l}$ (40-fold concentration). The total time of centrifuging ranged from
4 to $5 \mathrm{~h}$. Protein concentration was measured using the Bio-Rad DC Protein Assay Kit (Bio-Rad, Hemel Hempstead, UK) and ranged from 0.4 to $1.0 \mu \mathrm{g} \mu \mathrm{l}^{-1}$.

2D gel electrophoresis and mass spectrometry. $\mathrm{CM}$ were collected from normal fibroblasts (NHOF1, NHOF 2), normal fibroblasts treated with $\mathrm{H}_{2} \mathrm{O}_{2}$ (Fibs $+\mathrm{H}_{2} \mathrm{O}_{2}$ ) and fibroblasts from genetically stable (GS-OSCC/BICR66F; GS-OSCC/BICR73F) and unstable (GU-OSCC/BICR18F; GU-OSCC/H357F) OSCC. Samples were concentrated using Microcon-10 centrifugal filter devices (Millipore) and washed extensively in $10 \mathrm{~mm}$ Tris- $\mathrm{HCl}, \mathrm{pH} 7$ to a final volume of $50 \mu \mathrm{l}$. Concentrated extracts were made up to $200 \mu \mathrm{l}$ with $7 \mathrm{M}$ Urea, $2 \mathrm{M}$ Thiourea, 4\% CHAPS, $0.002 \%$ Bromophenol Blue, 0.5\% IPG Buffer pH3-11NL and 1.2\% Destreak reagent (GE Life Sciences, Little Chalfont, Buckinghamshire, UK). Samples were left at ambient temperature for $1 \mathrm{~h}$ and then loaded on to $11-\mathrm{cm}$ Immobiline DryStrips (first-dimension IPG strips, pH3-11, non-linear; GE Life Sciences) by passive rehydration. Following rehydration overnight, isoelectric focussing was performed using the Ettan IPGphor3 (GE Life Sciences), according to the manufacturer's instructions. The focussed IPG strips were incubated for $15 \mathrm{~min}$ in $10 \mathrm{ml}$ SDS equilibration buffer $(50 \mathrm{~mm}$ Tris- $\mathrm{HCl}, \mathrm{pH} 8.8,6 \mathrm{~m}$ urea, 30\% glycerol, 2\% SDS, $0.002 \%$ bromophenol blue) containing $100 \mathrm{mg}$ DTT and then in $10 \mathrm{ml}$ equilibration buffer containing $250 \mathrm{mg}$ iodoacetamide for a further $15 \mathrm{~min}$. The equilibrated strips were applied to the surface of vertical $12.5 \%$ SDS-polyacrylamide gels, and the proteins were separated in the second dimension using the Ettan DALT 6 separation unit (GE Life Sciences) at $5 \mathrm{~mA} /$ gel for $1 \mathrm{~h}, 8 \mathrm{~mA} /$ gel for $1 \mathrm{~h}$ and then $13 \mathrm{~W} / g e l$, until completion. The gels were fixed for $1 \mathrm{~h}$ in 50\% methanol/10\% acetic acid and stained overnight using Sypro Ruby total protein stain (Life Technologies Ltd, Paisley, Scotland).

Following de-staining in 10\% methanol/7\% acetic acid, the gels were examined using a Typhoon 9400 variable mode imager (GE Life Sciences). Protein spots of interest were excised from the gel using the Investigator ProPic automated spot picker and digested with trypsin using the ProGest automated digestion unit (Perkin Elmer Life Sciences, Buckinghamshire, UK). The resulting peptides were analysed using a 4700 MALDI-Tof/Tof mass spectrometer (Applied Biosystems, Life Technologies Ltd) to give a peptide mass fingerprint and peptide sequence information. The data were searched against the NCBInr database using the Mascot search engine from Matrix Science (London, UK) to identify specific proteins. Mass spectrometry details were recorded in positive ion mode on an Applied Biosystems 4700 MALDI mass spectrometer. MS spectra were recorded in reflector mode. For MSMS analysis, the top nine most intense, non-tryptic, precursors were selected for fragmentation by collision-induced dissociation. Neither baseline subtraction or smoothing were applied to recorded spectra. MS and MSMS data were analysed using GPS Explorer 3.5 (Applied Biosystems). MS peaks were filtered with a minimum signal-tonoise ratio of 35 to exclude mass derived from trypsin autolysis. MSMS peaks were filtered to exclude peaks with a signal-to-noise ratio $<35$ over a mass range of $20-50 \mathrm{Da}$ below the precursor mass. Data were analysed using the MASCOT algorithm (Matrix Science) and the NCBI database. A maximum number of missed cleavages of 1 and a charge state of +1 were assumed for precursor ions. A precursor tolerance of 100 p.p.m. and an MS/MS fragment tolerance of $0.15 \mathrm{Da}$ were used in the database search. Routinely, samples were analysed with methionine oxidation, considered to be a variable modification.

Zymography. Gelatinase activity and secretion in fibroblast CM were determined using SDS-polyacrylamide gel zymography (Cirillo et al, 2007a). Briefly, $20 \mu$ l aliquots of CM were mixed with $20 \mu \mathrm{l} 2 \times$ Lemmli sample buffer and heated at $50^{\circ} \mathrm{C}$ for $5 \mathrm{~min}$. Samples were electrophoresed on a $10 \%$ 
SDS-polyacrylamide gel containing $0.5 \mathrm{mg} \mathrm{ml}^{-1}$ gelatin. Then the gels were washed in $2.5 \%$ Triton X-100 ( $3 \times$, each for $10 \mathrm{~min})$ to remove SDS and incubated overnight at $37^{\circ} \mathrm{C}$ in substrate buffer (50 mM Tris- $\mathrm{HCl}, \mathrm{pH} 7.8 ; 10 \mathrm{~mm} \mathrm{CaCl}_{2} ; 0.1 \%$ Triton $\mathrm{X}-100$ ) to allow the protease to digest its substrate. The following day, the gels were washed in distilled $\mathrm{H}_{2} \mathrm{O}$ and stained with Coumassie Brilliant Blue R-250 (500 ml methanol, $400 \mathrm{ml}$ distilled $\mathrm{H}_{2} \mathrm{O}, 100 \mathrm{ml}$ glacial acetic acid, $2.5 \mathrm{~g}$ Coumassie Brilliant Blue R-250) and briefly destained in a de-staining solution $\left(785 \mathrm{ml}\right.$ distilled $\mathrm{H}_{2} \mathrm{O}, 165 \mathrm{ml}$ ethanol, $50 \mathrm{ml}$ glacial acetic acid). Proteolytic activity appeared as clear bands on a blue background.

Immunoprecipitation (IP) and western blotting (WB). Pelleted cells were suspended in IP buffer ( $50 \mathrm{~mm}$ Tris- $\mathrm{HCl}, \mathrm{pH} 7.5$, $150 \mathrm{~mm} \mathrm{NaCl}, 0.5 \%$ Nonidet P-40, $1 \mathrm{~mm}$ dithiothreitol, $1 \mathrm{~mm}$ PMSF) and centrifuged for $30 \mathrm{~min}$ at $16000 \mathrm{~g}$. Supernatants containing equal amounts of protein $(300 \mu \mathrm{g})$ were precleared with $15 \mu \mathrm{l}$ protein $\mathrm{A}$-Sepharose and then incubated for $1 \mathrm{~h}$ with a mouse monoclonal IgG against amino acids 557-569 of MMP-2, after which $15 \mu \mathrm{l}$ protein A-Sepharose was added for $2 \mathrm{~h}$. After centrifugation at $2300 \mathrm{~g}$ for $10 \mathrm{~min}$, beads containing antigenantibody complexes were washed, and $\mathrm{WB}$ was performed as detailed (Cirillo et al, 2007b). A goat anti-MMP-2 IgG was used as a primary antibody in order to reduce cross-reactivity of the secondary antibody against the Fc fraction of the immunoprecipitated anti-MMP-2 IgG of mouse origin. Details of antibodies, concentrations and suppliers are summarised in Supplementary Table S1.

Inhibition of MMP-2 and TGF- $\beta$. MMP-2 was inhibited by the addition of anti-MMP-2 monoclonal antibody $\left(4 \mu \mathrm{g} \mathrm{ml}^{-1}\right.$, Cat no. MAB13405; Millipore) to GU-OSCC/H357F cultures before the collection of CM. To inhibit TGF- $\beta, 5 \mu \mathrm{ml} \mathrm{ml}^{-1}$ monoclonal antibody to TGF- $\beta 1,-\beta 2$ and $-\beta 3$ (Cat no. MAB1835; R \& D Systems, Abingdon, Oxfordshire, UK) was added to the fibroblast $\mathrm{CM}$ for $30 \mathrm{~min}$ at $37^{\circ} \mathrm{C}$.

Epithelial adhesion. Intercellular adhesion of keratinocytes treated with fibroblast $\mathrm{CM}$ was measured using the Dispase dissociation assay (Cirillo and Prime, 2009). In all, $1 \times 10^{4}$ keratinocytes were cultured in six-well plates under standard conditions until $\sim 95 \%$ confluent. The culture media were decanted, the cells washed with PBS $(3 \times)$ and then incubated with $4 \mathrm{ml}$ fibroblast $\mathrm{CM}$ for $48 \mathrm{~h}$. The fibroblast $\mathrm{CM}$ was decanted from the keratinocyte cultures, and the cells were washed with PBS $(2 \times)$. Then, the keratinocytes were incubated with $2 \mathrm{ml} 0.5 \%$ Dispase II (Sigma Aldrich Ltd, Gillingham, Dorset, UK) at $37^{\circ} \mathrm{C}$ for 15-20 min such that they were separated from the base of the culture dish as a single sheet. The Dispase was carefully decanted, and the cell sheet was gently washed with $3 \mathrm{ml}$ PBS before transferring to universal tubes containing $4 \mathrm{ml}$ PBS. The tubes were then sealed and shaken by hand up and down $(20 \times)$. The content of each tube was returned back to the six-well plates where $10 \mu \mathrm{l}$ crystal violet was added, and the total number of detached fragments was counted. The number of detached fragments ( $>3 \mathrm{~mm}$ ), determined by placing the six-well plate over a grid on a white paper, was taken as a measure of intercellular keratinocyte adhesive strength.

Epithelial invasion. Epithelial invasion was examined as described previously (Tselepis et al, 1985; Hassona et al, 2013). Briefly, collagen gels were prepared by mixing $4 \mathrm{ml} 3.75 \mathrm{mg} \mathrm{ml}^{-1}$ type 1 collagen from rat tail tendon (BD Biosciences, Oxford, UK), $5 \mathrm{ml}$ fibroblast $\mathrm{CM}$ and $1 \mathrm{ml} 0.125 \mathrm{M} \mathrm{NAOH} / 0.26 \mathrm{M} \mathrm{NaHCO}_{3}$. The collagen mixture was aliquoted into 24 -well plates and allowed to set for approximately $3 \mathrm{~h}$ at $37^{\circ} \mathrm{C}$. In all, $2.5 \times 10^{4} \mathrm{H} 357$ epithelial cells in $500 \mu$ l DMEM-F12/10\%FBS were gently layered on top of the collagen surface, and after $72 \mathrm{~h}$, the gels were gently washed with PBS, treated with trypsin for 20 min under standard conditions and then the number of trypsinised cells was counted. The collagen gels were melted by heating on a hot plate for $2-4 \mathrm{~min}$ at $50^{\circ} \mathrm{C}$, the collagen was diluted in PBS and the number of cells was counted in this solution. The invasion index was calculated by dividing the number of cells in the gel by the number of the cells in trypsin.

Statistics. Unless otherwise indicated, the experiments were repeated $3 \times$; the values cited were the mean of the repeats \pm s.d. Data were analysed using the one-way analysis of variance with Tukey's multiple comparison test being used as a post test. $P<0.05$ was considered statistically significant.

\section{RESULTS}

Protein expression in fibroblast CM. In view of the identification of the SASP (Coppé et al, 2008), we reasoned that CM from senescent fibroblasts would show an increased protein concentration relative to non-senescent cells. The results demonstrated that when the protein concentration was normalised to cell number, CM from fibroblasts from GU-OSCC (H357F, H314F, BICR3F) contained significantly more protein (mean $0.73 \pm 0.075 \mu \mathrm{g} \mu \mathrm{l}^{-1}$ ) than CM from fibroblasts from normal mucosa (NHOF1, NHOF2, NHOF6; mean $0.26 \pm 0.032 \mu \mathrm{g} \mu \mathrm{l}^{-1}$ ) and GS-OSCC (BICR66F, BICR73F, BICR59F; mean 0.32 $\pm 0.055 \mu \mathrm{g} \mu \mathrm{l}^{-1}$ ) (Figure 1).

Identification of MMP-2 in senescent fibroblast CM. 2D gel electrophoresis was used to identify secreted proteins that were differentially expressed in $\mathrm{CM}$ from senescent fibroblasts (GU-OSCC/H357F, GU-OSCC/BICR18F, $\mathrm{H}_{2} \mathrm{O}_{2}$-treated NHOF1) relative to non-senescent fibroblasts (GS-OSCC/BICR66F, NHOF1) (Figure 2). Nine spots from the senescent fibroblast gels that were absent in the non-senescent fibroblast gels were selected randomly for further analysis using a 4700 MALDI-Tof/Tof mass spectrometer. The data were searched against the NCBInr Human database using the Mascot search engine from Matrix Science to identify specific proteins. Identified proteins with a protein score above the Mascot-defined significance threshold of 65 are summarised in Table 1.

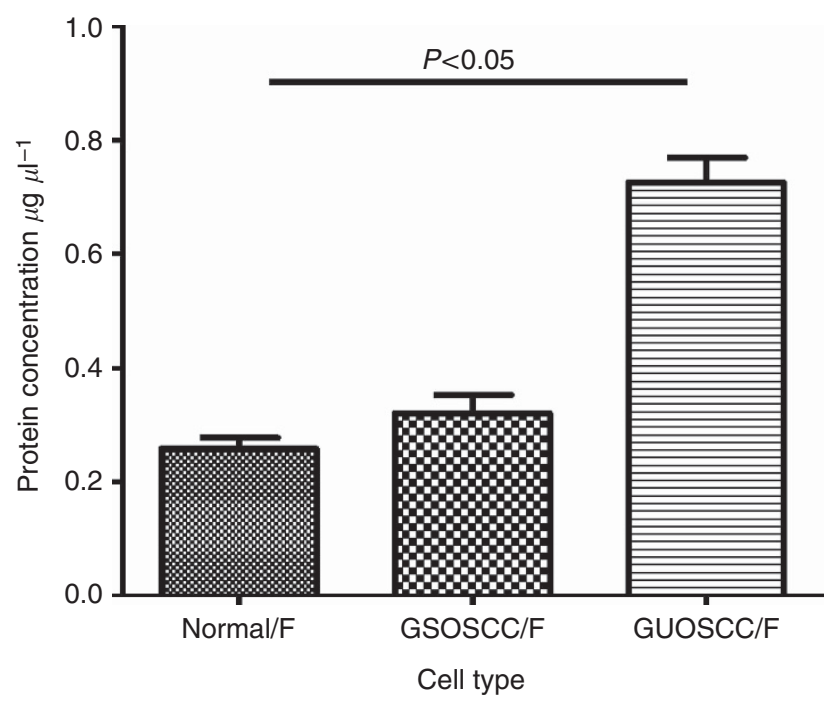

Figure 1. Mean protein concentration in fibroblast $\mathrm{CM}$. CM was collected from normal fibroblasts (NHOF1, NHOF2, NHOF6), fibroblasts from GS-OSCC (BICR66F, BICR73F, BICR59F) and fibroblasts from GU-OSCC (H314F, H357F, BICR3F). CM derived from senescent fibroblasts (GU-OSCC) contained significantly more protein than non-senescent fibroblasts from normal mucosa and GS-OSCC $(P<0.05)$. 


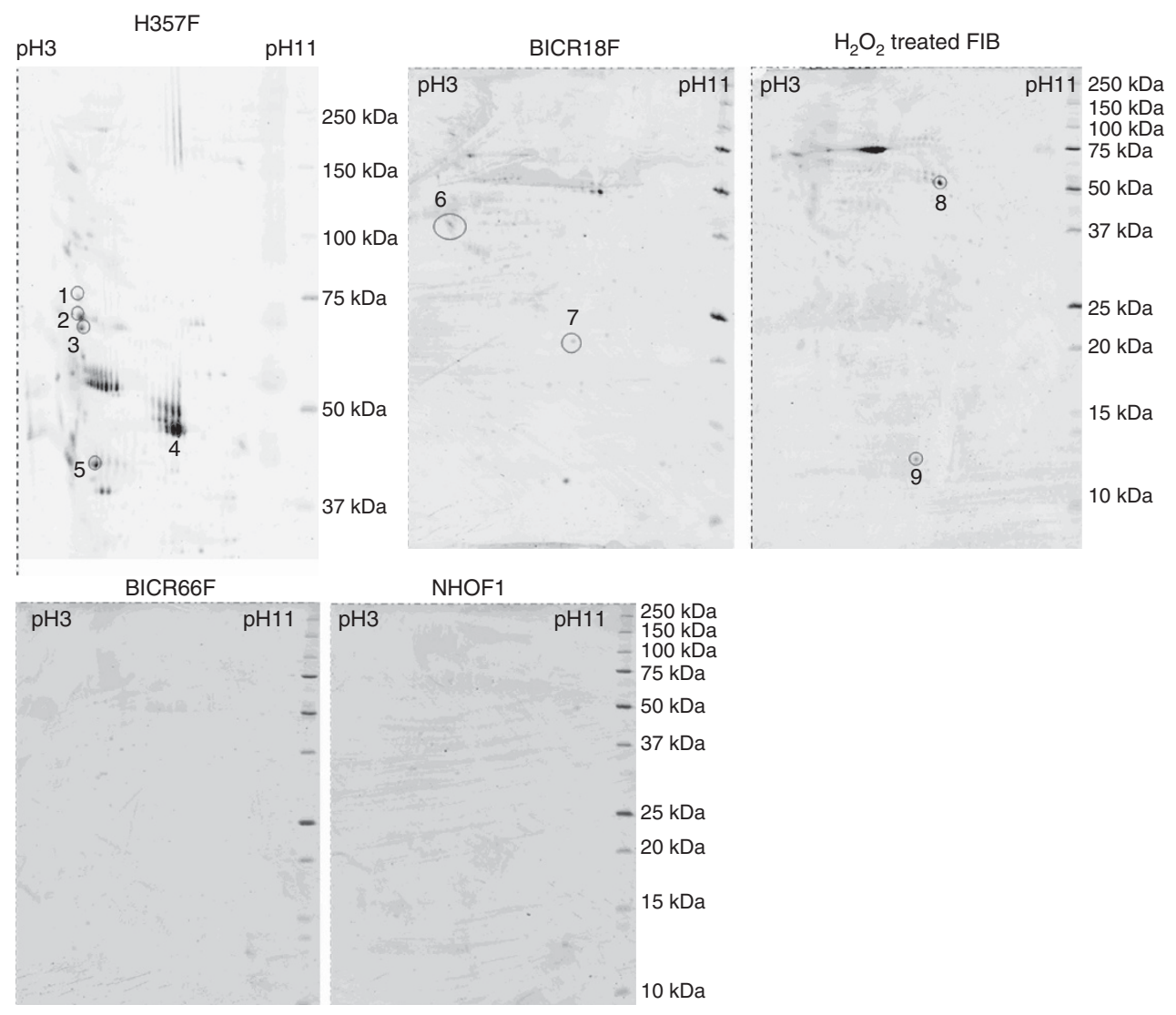

Figure 2. 2D gel electrophoresis of $\mathrm{CM}$ from senescent fibroblasts (H357F; BICR18F; $\mathrm{H}_{2} \mathrm{O}_{2}$-treated NHOF1) showed more protein spots than non-senescent fibroblasts (NHOF1; BICR66F). The protein spots selected for mass spectrometry analyses are outlined in red.

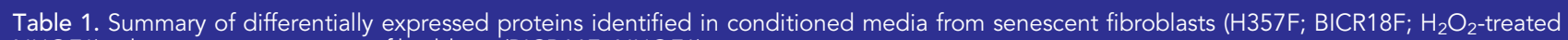
NHOF1) relative to non-senescent fibroblasts (BICR66F, NHOF1)

\begin{tabular}{|c|c|c|c|c|c|c|}
\hline $\begin{array}{l}\text { Spot } \\
\text { no. }\end{array}$ & Gel & Identified proteins & $\begin{array}{l}\text { Accession } \\
\text { number }\end{array}$ & $\begin{array}{l}\text { Theoretical } \\
\text { pl }\end{array}$ & $\begin{array}{c}\text { Theoretical } \\
\text { MW }\end{array}$ & $\begin{array}{l}\text { Protein } \\
\text { score }\end{array}$ \\
\hline 1 & H357F & Glucose-regulated protein (GRP-78)/heat-shock protein 5 & 16507237 & 5.07 & 72402.5 & 668 \\
\hline 2 & H357F & $\begin{array}{l}\text { Gelatinase A (MMP2) } \\
\text { Collagenase type IV precursor }\end{array}$ & $\begin{array}{r}5822007 \\
180671\end{array}$ & $\begin{array}{l}5.2 \\
5.2\end{array}$ & $\begin{array}{l}71841.5 \\
73279.2\end{array}$ & $\begin{array}{l}623 \\
608\end{array}$ \\
\hline 3 & H357F & $\begin{array}{l}\text { Chain A, gelatinase A (MMP2) } \\
\text { Collagenase type IV precursor }\end{array}$ & $\begin{array}{r}5822007 \\
180671\end{array}$ & $\begin{array}{l}5.2 \\
5.2\end{array}$ & $\begin{array}{l}71841.5 \\
73279.2\end{array}$ & $\begin{array}{l}582 \\
580\end{array}$ \\
\hline 4 & H357F & $\begin{array}{l}\text { Chain A, human Prommp-1 } \\
\text { Chain A, human fibroblasts collagenase }\end{array}$ & $\begin{array}{r}58176727 \\
114793614\end{array}$ & $\begin{array}{l}6.43 \\
6.06\end{array}$ & $\begin{array}{l}51982.7 \\
42265.6\end{array}$ & $\begin{array}{l}511 \\
363\end{array}$ \\
\hline 5 & H357F & ACTB protein & 15277503 & 5.5 & 40536.2 & 536 \\
\hline 6 & BICR18F & Secreted protein, acidic, cysteine-rich (SPARC) (osteonictin) & 119582071 & 4.78 & 36939.7 & 207 \\
\hline 7 & BICR18F & TIMP-2 & 119609945 & 6.81 & 20695.1 & 125 \\
\hline 8 & $\mathrm{H}_{2} \mathrm{O}_{2}$-treated FIB & $\begin{array}{l}\text { Chain A, human Prommp-1 } \\
\text { MMP1 preprotein }\end{array}$ & $\begin{array}{l}58176727 \\
62897673\end{array}$ & $\begin{array}{l}6.43 \\
6.57\end{array}$ & $\begin{array}{l}51982.7 \\
46691\end{array}$ & $\begin{array}{l}499 \\
495\end{array}$ \\
\hline 9 & $\mathrm{H}_{2} \mathrm{O}_{2}$-treated FIB & $\begin{array}{l}\text { Hla-A2 } \\
\text { Hla-B27 } \\
\text { Chain B, immune receptor }\end{array}$ & $\begin{array}{r}229995 \\
230014 \\
66361122\end{array}$ & $\begin{array}{l}6.46 \\
6.07 \\
5.76\end{array}$ & $\begin{array}{l}11596.7 \\
11837.8 \\
12121\end{array}$ & $\begin{array}{l}69 \\
69 \\
68\end{array}$ \\
\hline
\end{tabular}

MMP-2 was selected for further study because of: (1) its importance in head and neck cancer (HNSCC; Rosenthal and Matrisian, 2006); certain MMPs are known to be upregulated in CAFs from HNSCC (Rosenthal et al, 2004); its expression in the SASP is controversial (Coppé et al, 2008; Pitiyage et al, 2011).
Function of MMP-2. MMP-2 is secreted as a propeptide and needs to be cleaved in order to be biologically active. SDSpolyacrylomide zymography was used to examine MMP-2 activity. The active form of MMP-2, as demonstrated by the presence of gelatinolitic activity in the zymograms, was detected in senescent 
fibroblast CM (GU-OSCC/H357F, GU-OSCC/BICR18F, $\mathrm{H}_{2} \mathrm{O}_{2}$-treated NHOF1) but not in $\mathrm{CM}$ from non-senescent fibroblasts (GS-OSCC/BICR66F, NHOF1), (Figure 3A). The presence of two bands specific for MMP-2 in the CM, including a $\sim 64-\mathrm{Kd}$ band corresponding to the active form of MMP-2, was confirmed by western blotting using a monoclonal antibody against MMP-2 (Figure 3B).

Because it has been shown that gelatinases, including MMP-2, can cleave cell-cell adhesion molecules (Weiske et al, 2001; Cirillo et $a l, 2007 \mathrm{c}$ ) and given the key role of intercellular adhesion in preventing epithelial invasion (Tselepis et al, 1985; Perl et al, 1998), we wished to determine whether stromal-derived MMP-2 regulated keratinocyte adhesion and invasion. MMP-2 activity was virtually inhibited using an anti-MMP-2 monoclonal antibody, and the absence of active MMP-2 was confirmed using zymography (Supplementary Figure S1). Inhibition of MMP-2 activity in senescent fibroblast CM (GU-OSCC/H357F) resulted in a significant $(P<0.05)$ reduction in the capacity of these cells to induce dissociation of $\mathrm{H} 357$ keratinocytes, as demonstrated in the Dispase dissociation assay (Figure 4A). At the molecular level, incubation of keratinocytes (H357) with CM from GU-OSCC/ $\mathrm{H} 357 \mathrm{~F}$ was associated with formation of a $75-\mathrm{kDa}$ proteolytic fragment of the adhesion molecule DSG3 (Cirillo et al, 2008), which was partially inhibited by pretreatment with an anti-MMP-2

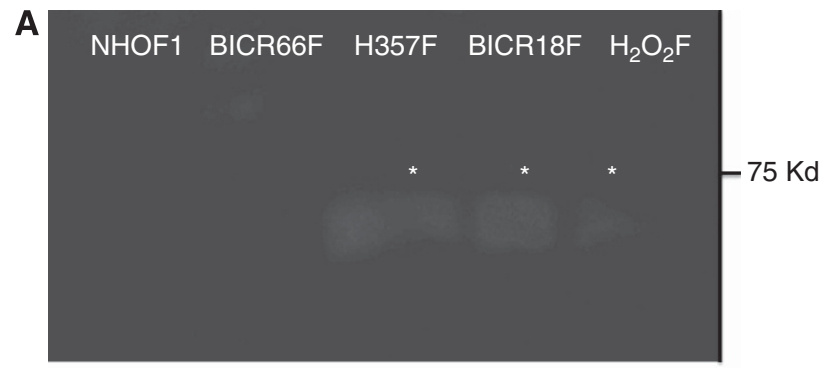

B

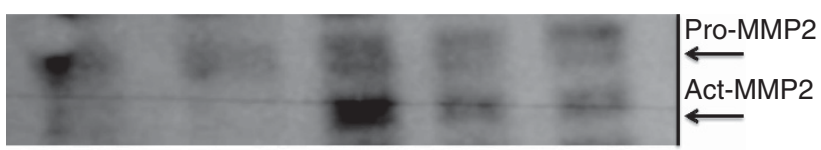

Figure 3. Gelatin zymography $(A)$ and western blot analysis $(B)$ of $C M$ from senescent (H357F; BICR18F; H2O2-treated NHOF1) and nonsenescent (BICR66F; NHOF1) fibroblasts. The data show gelatinase activity (molecular weight $75 \mathrm{Kd}$ ) and active MMP-2 (molecular weight $64 \mathrm{Kd}$ ) in $\mathrm{CM}$ from senescent but not non-senescent cells.

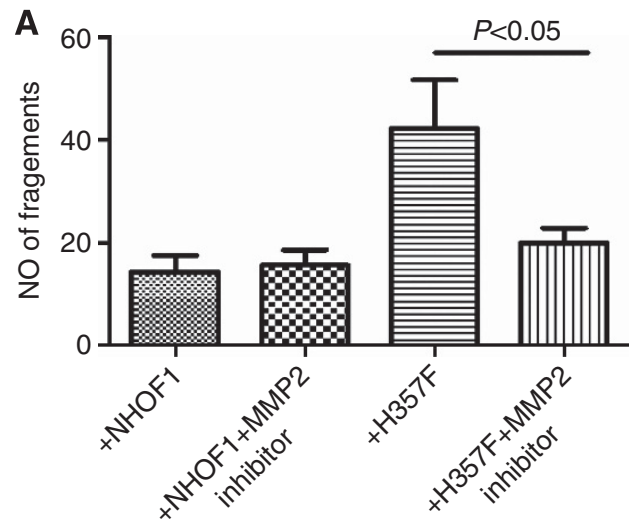

Type of media blocking antibody (Supplementary Figure S2). Similarly, inhibition of MMP-2 activity in GU-OSCC/H357F resulted in a significant $(P<0.05)$ reduction in the ability of these senescent fibroblasts to induce invasion of $\mathrm{H} 357$ keratinocytes into collagen gels (Figure 4B). Inhibition of MMP-2 activity in CM from nonsenescent fibroblasts (NHOF1) had no effect on keratinocyte dissociation or invasion (Figures $4 \mathrm{~A}$ and $\mathrm{B}$ ). Consistent data were obtained when using different fibroblast cell strains from both genetically stable and unstable OSCC (Supplementary Figure S3).

MMP-2 acts with TGF- $\beta$ to promote tumour invasion. We have shown recently that senescent fibroblasts exert pro-invasive effects via mechanisms that involve TGF- $\beta$ (Hassona et al, 2013). In view of the fact that MMP-2 proteolytically cleaves and activates latent TGF- $\beta$ (Yu and Stamenkovic, 2000), we reasoned that stromalderived MMP-2 might act in conjunction with TGF- $\beta$ to promote keratinocyte invasion. We show that inhibition of both MMP-2 and TGF- $\beta$ in CM from senescent fibroblasts (GU-OSCC/H357F) caused more inhibition of keratinocyte invasion compared with inhibition of either MMP-2 or TGF- $\beta$ alone (Figure 5). Our data strongly suggest that MMP- 2 and TGF- $\beta$ operate additively to disrupt $\mathrm{H} 357$ adhesion.

\section{DISCUSSION}

In this study, we examined fibroblast $\mathrm{CM}$ from a variety of different fibroblast types and show increased protein concentration in media derived from senescent CAFs (GU-OSCC) relative to non-senescent fibroblasts (GS-OSCC CAFs, normal fibroblasts). The findings support the concept that senescent fibroblasts secrete a plethora of factors associated with inflammation and malignancy collectively known as the SASP (Coppé et al, 2008). We used 2D gel electrophoresis and mass spectrometry to identify key proteins of the SASP that were differentially expressed between senescent (GU-OSCC) and non-senescent CAFs (GS-OSCC); $\mathrm{H}_{2} \mathrm{O}_{2}$-treated NHOF1 and untreated NHOF1 were used as positive and negative controls, respectively. We showed differential expression of MMP-2, MMP-1, TIMP-2, collagenase, osteonictin, glucose regulated protein (GRP-78) and ACTB protein ( $\beta$-actin). Certain MMPs, osteonictin and TIMP-2 have been reported previously in senescent cells (Coppé et al, 2008; Dean and Nelson, 2008; Kuilman \& Peeper, 2009), but the identification of GRP-78, a member of the heat-shock protein-70 (HSP-70) family, was novel. HSPs are known to be overexpressed in a wide range of human cancers and have been implicated in the regulation of tumour cell

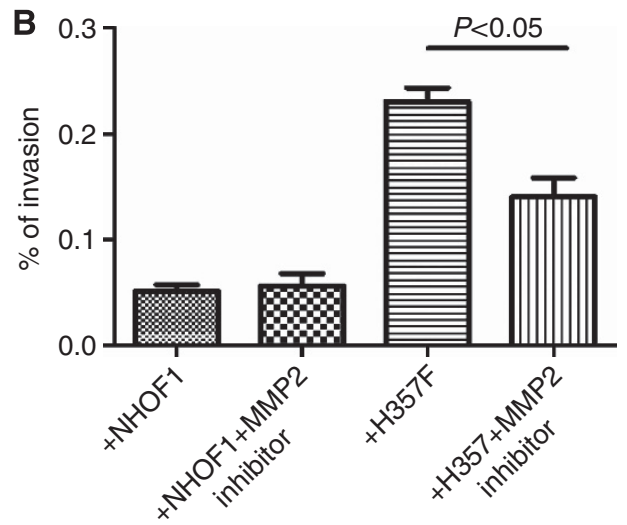

Type of media

Figure 4. Effect of MMP-2 inhibition on the pro-dissociative and pro-invasive effect of CM from senescent fibroblasts(GU-OSCC/H357F) on H357 keratinocytes. Inhibition of stromal-derived MMP-2 resulted in a significant reduction in the ability of senescent fibroblasts to induce dissociation of H357 keratinocytes (A) and keratinocyte invasion (B). CM from normal oral fibroblasts (NHOF1) was used as a negative control. 


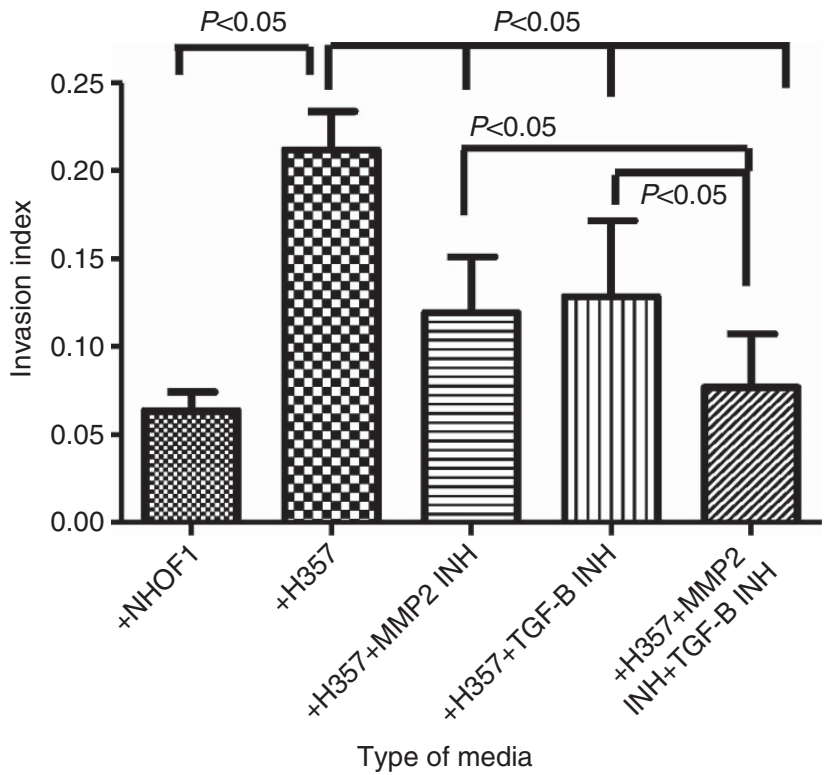

Figure 5. The effect of combined inhibition of MMP-2 and TGF- $\beta$ in $\mathrm{CM}$ from senescent fibroblasts (GU-OSCC/H357F) on keratinocyte invasion. Inhibition of both MMP-2 and TGF- $\beta$ resulted in reduction in the ability of the untreated $\mathrm{CM}$ to induce invasion of $\mathrm{H} 357$ keratinocytes compared with the inhibition of either MMP-2 or TGF- $\beta$ alone.

proliferation, differentiation, invasion and metastasis (Ciocca and Calderwood, 2005). As far as we are aware, the presence of HSPs has not been reported in the SASP. Interestingly, non-secreted proteins such as fibronectin, collagen and laminin have also been found in the SASP, but the identification of $\beta$-actin (ACTB protein), a cytoskeletal non-secreted protein, is novel. Whether these non-secreted proteins actively contribute to the ECM or whether they are simply present as a result of cellular lysis due to the incubation of cells in serum-free media before culture media collection is unclear.

MMPs are a diverse group of zinc-dependent endopeptidases that have importance in HNSCC (Rosenthal and Matrisian, 2006). In the present study, we demonstrate the presence of active MMP-2 in CM from senescent fibroblasts using gelatin zymography, a highly sensitive technique to analyse MMPs in biological samples (Hawkes et al, 2001). Although the expression of MMP-2 by senescent fibroblasts is controversial (Coppé et al, 2008; Pitiyage et al, 2011), recent data indicate that pro-MMP-2 (inactive) is secreted by CAFs in OSCC (Fullar et al, 2012). In the present study, we show that the inhibition of MMP-2 activity results in a decrease in the capacity of senescent fibroblasts to promote keratinocyte dis-cohesion and invasion in vitro. The results support the concept that MMP-2 promotes tumour invasion into collagen gels in vitro by disrupting epithelial adhesion; the findings extend previous data (Zhang et al, 2006).

Previous studies have shown that TGF- $\beta 1$ has the capacity to upregulate MMP-2 (Lin et al, 2007), and conversely, MMP-2 can activate latent TGF- $\beta$ (Yu and Stamenkovic, 2000). These findings prompted us to investigate whether MMP-2 and TGF- $\beta$ acted in concert in the stromal regulation of keratinocyte invasion. We demonstrate that the combined inhibition of MMP-2 and TGF- $\beta$ results in a significant reduction in the ability of senescent fibroblasts to induce keratinocyte invasion into collagen gels compared with the inhibition of either MMP- 2 or TGF- $\beta$ alone. The additive nature of MMP-2 and TGF- $\beta$ inhibition on H357 adhesion is interesting. These findings suggest that MMP-2 is regulated by factors other than TGF- $\beta$ and/or that MMP- 2 and TGF- $\beta$ are targeting different keratinocyte adhesion molecules.
MMPs-3, -7 and -9, for example, cleave the ectodomain of E-cadherin leading to inhibition of intercellular adhesion (Noë et al, 2001; Orlichenko and Radisky, 2008). Further, MMP-2/9 cleave Desmoglein 3 (DSG3), a type I integral membrane glycoproteins that belong to the Cadherin family of calciumdependent cell adhesion molecules, in skin blistering disorders (Weiske et al, 2001; Cirillo et al, 2007c). DSG3 is the main desmocadherin expressed by keratinocyte monolayers in vitro (Koch et al, 1992; Denning et al, 1998) and is found in all cell layers of oral mucosal epithelium in vivo (Mahoney et al, 1999). With respect to TGF- $\beta$, recent studies have shown that CAF-derived TGF- $\beta$ can induce an epithelial-mesenchymal transition in breast cancer cells (Yu et al, 2014), and the cytokine is known to promote tissue repair and fibrosis in myofibroblasts via the focal adhesion kinase (FAK) pathway (Leask, 2012). Whether senescent CAF-derived TGF- $\beta$ regulates keratinocyte adhesion through FAK, however, is unknown. The findings illustrate the complexity of stromalepithelial interactions. Not only do constituents of the SASP interact directly with malignant keratinocytes to modulate cell behaviour but they also appear to interact with one another and with other components of the tumour microenvironment.

MMPs are regulated precisely during synthesis and secretion, at the time of activation of the pro-enzyme and/or by localisation, clearance and inhibition of the active enzyme (Ra and Parks, 2007). With respect to activation, previous studies have shown that MMP-2 is activated by osteopontin (Zhang et al, 2011), reactive oxygen species (ROS; Svineng et al, 2008), TGF- $\beta 2$ (Baumann et al, 2009) and TIMP-2 (Itoh et al, 2001; Rosenthal and Matrisian, 2006), among other mechanisms. It is particularly interesting, therefore, that osteopontin is a key constituent of the SASP (Coppé et al, 2008) and is known to promote epithelial tumour development (Pazolli et al, 2009). In addition, we have demonstrated that malignant keratinocytes from GU-OSCC induce senescence in normal fibroblasts in a ROS- and TGF- $\beta$-dependent manner (Hassona et al, 2013). Further, we have shown that radiation-induced fibroblast senescence is associated with increased TIMP-1 and TIMP-2, and both TIMP-1 and TIMP-2 are increased in the media of fibroblast cultures from patients with the premalignant condition oral sub-mucous fibrosis where senescent cells are more abundant (Pitiyage et al, 2012). It may be, therefore, that the activation of MMP-2 is a key event in mediating the effects of CAFs on epithelial malignancy. The role of MMP-2, however, is complex. On the one hand, the enzyme appears to cause epithelial dis-cohesion and promote epithelial invasion in vitro, while on the other, we and others have shown that fibroblast-derived MMP-2 may ameliorate excessive fibrosis by degrading collagen (Jun and Lau, 2010; Pitiyage et al, 2011). Further studies are undergoing in our labs to clarify the role of MMPs in relation to the epithelial dis-cohesive effects of CAFs.

\section{ACKNOWLEDGEMENTS}

Y Hassona was supported by a Clinical Fellowship from the University of Jordan.

\section{REFERENCES}

Agrawal N, Frederick MJ, Pickering CR, Bettegowda C, Chang K, Li RJ, Fakhry C, Xie TX, Zhang J, Wang J, Zhang N, El-Naggar AK, Jasser SA, Weinstein JN, Trevino L, Drummond JA, Muzny DM, Wu Y, Wood LD, Hruban RH, Westra WH, Koch WM, Califano JA, Gibbs RA, Sidransky D, Vogelstein B, Velculescu VE, Papadopoulos N, Wheeler DA, Kinzler KW, Myers JN (2011) Exome sequencing of head and neck squamous cell 
carcinoma reveals inactivating mutations in NOTCH1. Science 333(6046): $1154-1157$.

Baumann F, Leukel P, Doerfelt A, Beier CP, Dettmer K, Oefner PJ, Kastenberger M, Kreutz M, Nickl-Jockschat T, Bogdahn U, Bosserhoff AK, Hau P (2009) Lactate promotes glioma migration by TGF-beta2dependent regulation of matrix metalloproteinase-2. Neuro Oncol 11(4): 368-380.

Ciocca DR, Calderwood SK (2005) Heat shock proteins in cancer: diagnostic, prognostic, predictive, and treatment implications. Cell Stress Chaperones 10(2): 86-103.

Cirillo N, Lanza M, Rossiello L, Gombos F, Lanza A (2007a) Defining the involvement of proteinases in pemphigus vulgaris: evidence of matrix metalloproteinase- 9 overexpression in experimental models of disease. J Cell Physiol 212(1): 36-41.

Cirillo N, Gombos F, Lanza A (2007b) Pemphigus vulgaris immunoglobulin G can recognize a 130,000 MW antigen other than desmoglein 3 on peripheral blood mononuclear cell surface. Immunology 121(3): 377-382.

Cirillo N, Femiano F, Gombos F, Lanza A (2007c) Metalloproteinase 9 is the outer executioner of desmoglein 3 in apoptotic keratinocytes. Oral Dis 13(3): 341-345.

Cirillo N, Campisi G, Gombos F, Perillo L, Femiano F, Lanza A (2008) Cleavage of desmoglein 3 can explain its depletion from keratinocytes in pemphigus vulgaris. Exp Dermatol 17(10): 858-863.

Cirillo N, Prime SS (2009) Desmosomal interactome in keratinocytes: a systems biology approach leading to an understanding of the pathogenesis of skin disease. Cell Mol Life Sci 66(21): 3517-3533.

Coppé JP, Patil CK, Rodier F, Sun Y, Muñoz DP, Goldstein J, Nelson PS, Desprez PY, Campisi J (2008) Senescence-associated secretory phenotypes reveal cell-nonautonomous functions of oncogenic RAS and the p53 tumor suppressor. PLoS Biol 6(12): 2853-2868.

Dean JP, Nelson PS (2008) Profiling influences of senescent and aged fibroblasts on prostate carcinogenesis. Br J Cancer 98(2): 245-249.

Denning MF, Guy SG, Ellerbroek SM, Norvell SM, Kowalczyk AP, Green KJ (1998) The expression of desmoglein isoforms in cultured human keratinocytes is regulated by calcium, serum, and protein kinase $\mathrm{C}$. Exp Cell Res 239(1): 50-59.

Edington KG, Loughran OP, Berry IJ, Parkinson EK (1995) Cellular immortality: a late event in the progression of human squamous cell carcinoma of the head and neck. Is associated with p53 alteration and a high frequency of allele loss. Mol Carcinog 13(4): 254-265.

Fullar A, Kovalszky I, Bitsche M, Romani A, Schartinger VH, Sprinzl GM, Reichelman H, Dudas J (2012) Tumor cell and carcinoma-associated fibroblast interaction regulates matrix metalloproteinases and their inhibitors in oral squamous cell carcinoma. Exp Cell Res 318(13): 1517-1527.

Hanahan D, Weinberg RA (2011) Hallmarks of cancer: the next generation. Cell 144(5): 646-674.

Hassona Y, Cirillo N, Lim KP, Herman A, Mellone M, Thomas GJ, Pitiyage GN, Parkinson EK, Prime SS (2013) Progression of genotype-specific oral cancer leads to senescence of cancer associated fibroblasts and is mediated by oxidative stress and TGF- $\beta$. Carcinogenesis 34(6): 1286-1295.

Hawkes SP, Li H, Taniguchi GT (2001) Zymography and reverse zymography for detecting MMPs, and TIMPs. Methods Mol Biol 151: 399-410.

Hunter KD, Thurlow JK, Fleming J, Drake PJ, Vass JK, Kalna G, Higham DJ, Herzyk P, Macdonald DG, Parkinson EK, Harrison PR (2006) Divergent routes to oral cancer. Cancer Res 66(15): 7405-7413.

Itoh Y, Takamura A, Ito N, Maru Y, Sato H, Suenaga N, Aoki T, Seiki M (2001) Homophilic complex formation of MT1-MMP facilitates proMMP-2 activation on the cell surface and promotes tumor cell invasion. EMBO J 20(17): 4782-4793.

Jun JI, Lau LF (2010) The matricellular protein CCN1 induces fibroblast senescence and restricts fibrosis in cutaneous wound healing. Nat Cell Biol 12(7): 676-685.

Kalluri R, Zeisberg M (2006) Fibroblasts in cancer. Nat Rev Cancer 6(5): 392-401.

Koch PJ, Goldschmidt MD, Zimbelmann R, Troyanovsky R, Franke WW (1992) Complexity and expression patterns of the desmosomal cadherins. Proc Natl Acad Sci USA 89(1): 353-357.

Krtolica A, Parrinello S, Lockett S, Desprez PY, Campisi J (2001) Senescent fibroblasts promote epithelial cell growth and tumorigenesis: a link between cancer and aging. Proc Natl Acad Sci USA 98(21): 12072-12077.

Kuilman T, Peeper DS (2009) Senescence-messaging secretome: SMS-ing cellular stress. Nat Rev Cancer 9(2): 81-94.
Leask A (2012) Focal adhesion kinase: a key mediator of transforming growth factor beta signalling in fibroblasts. Adv Wound Care 2(5): 247-249.

Lim KP, Cirillo N, Hassona Y, Wei W, Thurlow JK, Cheong SC, Pitiyage G, Parkinson EK, Prime SS (2011) Fibroblast gene expression profile reflects the stage of tumour progression in oral squamous cell carcinoma. J Pathol 223(4): 459-469.

Lin SW, Ke FC, Hsiao PW, Lee PP, Lee MT, Hwang JJ (2007) Critical involvement of ILK in TGFbeta1-stimulated invasion/migration of human ovarian cancer cells is associated with urokinase plasminogen activator system. Exp Cell Res 313(3): 602-613.

Loughran O, Clark IJ, Bond J, Baker A, Berry IJ, Edington KG, Ly IS, Simmons R, Haw R, Black DM, Newbold RF, Parkinson EK (1997) Evidence for the inactivation of multiple replicative lifespan genes in immortalised human squamous cell carcinoma keratinocytes. Oncogene 14(16): 1955-1964.

Mahoney MG, Wang Z, Rothenberger K, Koch PJ, Amagai M, Stanley JR (1999) Explanations for the clinical and microscopic localization of lesions in pemphigus foliaceus and vulgaris. J Clin Invest 103(4): 461-468.

Noë V, Fingleton B, Jacobs K, Crawford HC, Vermeulen S, Steelant W, Bruyneel E, Matrisian LM, Mareel M (2001) Release of an invasion promoter E-cadherin fragment by matrilysin and stromelysin-1. J Cell Sci 114(1): 111-118.

Orlichenko LS, Radisky DC (2008) Matrix metalloproteinases stimulate epithelial-mesenchymal transition during tumor development. Clin Exp Metastasis 25(6): 593-600.

Pazolli E, Luo X, Brehm S, Carbery K, Chung JJ, Prior JL, Doherty J, Demehri S, Salavaggione L, Piwnica-Worms D, Stewart SA (2009) Senescent stromalderived osteopontin promotes preneoplastic cell growth. Cancer Res 69(3): 1230-1239.

Perl AK, Wilgenbus P, Dahl U, Semb H, Christofori G (1998) A causal role for E-cadherin in the transition from adenoma to carcinoma. Nature 392(6672): 190-193.

Pickering CR, Zhang J, Yoo SY, Bengtsson L, Moorthy S, Neskey DM, Zhao M, Ortega Alves MV, Chang K, Drummond J, Cortez E, Xie TX, Zhang D, Chung W, Issa JP, Zweidler-McKay PA, Wu X, El-Naggar AK, Weinstein JN, Wang J, Muzny DM, Gibbs RA, Wheeler DA, Myers JN, Frederick MJ (2013) Integrative genomic characterization of oral squamous cell carcinoma identifies frequent somatic drivers. Cancer Discov 3(7): 770-781.

Pitiyage GN, Lim KP, Gemenitzidis E, Teh MT, Waseem A, Prime SS, Tilakaratne WM, Fortune F, Parkinson EK (2012) Increased secretion of tissue inhibitors of metalloproteinases 1 and 2 (TIMPs -1 and -2) in fibroblasts are early indicators of oral sub-mucous fibrosis and ageing. J Oral Pathol Med 41(6): 454-462.

Pitiyage GN, Slijepcevic P, Gabrani A, Chianea YG, Lim KP, Prime SS, Tilakeratne WM, Fortune F, Parkinson EK (2011) Senescent mesenchymal cells accumulate in human fibrosis by a telomere-independent mechanism and ameliorate fibrosis through matrix metalloproteinases. J Pathol 223(5): 604-617.

Prime SS, Eveson JW, Stone AM, Huntley SP, Davies M, Paterson IC, Robinson CM (2004) Metastatic dissemination of human malignant keratinocyte cell lines following orthotopic transplantation reflects response to TGF-31. J Pathol 203(4): 927-932.

Ra HJ, Parks WC (2007) Control of matrix metalloproteinase catalytic activity. Matrix Biol 26(8): 587-596.

Rosenthal EL, Matrisian LM (2006) Matrix metalloproteinases in head and neck cancer. Head Neck 28(7): 639-648.

Rosenthal EL, McCrory A, Talbert M, Carroll W, Magnuson JS, Peters GE (2004) Expression of proteolytic enzymes in head and neck cancerassociated fibroblasts. Arch Otolaryngol Head Neck Surg 130(8): 943-947.

Stransky N, Egloff AM, Tward AD, Kostic AD, Cibulskis K, Sivachenko A, Kryukov GV, Lawrence MS, Sougnez C, McKenna A, Shefler E, Ramos AH, Stojanov P, Carter SL, Voet D, Cortez ML, Auclair D, Berger MF, Saksena G, Guiducci C, Onofrio RC, Parkin M, Romkes M, Weissfeld JL, Seethala RR, Wang L, Rangel-Escareno C, Fernandez-Lopez JC, Hidalgo-Miranda A, Melendez-Zajgla J, Winckler W, Ardlie K, Gabriel SB, Meyerson M, Lander ES, Getz G, Golub TR, Garraway LA, Grandis JR (2011) The mutational landscape of head and neck squamous cell carcinoma. Science 333(6046): 1157-1160.

Svineng G, Ravuri C, Rikardsen O, Huseby NE, Winberg JO (2008) The role of reactive oxygen species in integrin and matrix metalloproteinase expression and function. Connect Tiss Res 49(3): 197-202.

Tselepis C, Chidgey M, North A, Garrod D (1985) Desmosomal adhesion inhibits invasive behaviour. Proc Natl Acad Sci USA 95(14): 8064-8069. 
Weber RG, Scheer M, Born IA, Joos S, Cobbers JM, Hofele C, Reifenberger G, Zoller JE, Lichter P (1998) Recurrent chromosomal imbalances detected in biopsy material from oral premalignant and malignant lesions by combined tissue microdissection, universal DNA amplification, and comparative genomic hybridization. Am J Pathol 153(1): 295-303.

Weiske J, Schoneberg T, Schroder W, Hatzfeld M, Tauber R, Huber O (2001) The fate of desmosomal proteins in apoptotic cells. J Biol Chem 276(44): 41175-41181.

Wu CL, Roz L, McKown S, Sloan P, Read AP, Holland S, Porter S, Scully C, Paterson I, Tavassoli M, Thakker N (1999) DNA studies underestimate the major role of CDKN2A inactivation in oral and oropharyngeal squamous cell carcinomas. Genes Chromosomes Cancer 25(1): 16-25.

Yeudall WA, Paterson IC, Patel V, Prime SS (1995) Presence of human papillomavirus sequences in tumour-derived human oral keratinocytes which express mutant p53. Eur J Cancer B Oral Oncol 31B(2): 136-143.
Yu Q, Stamenkovic I (2000) Cell surface-localized matrix metalloproteinase-9 proteolytically activates TGF-beta and promotes tumor invasion and angiogenesis. Genes Dev 14(2): 163-176.

Yu Y, Xiao CH, Tan LD, Wang QS, Li XQ, Feng YM (2014) Cancer associated fibroblasts induce epithelial-mesenchymal transition of breast cancer cells through paracrine TGF- $\beta$ signalling. Br J Cancer 110(3): 724-732.

Zhang R, Pan X, Huang Z, Weber GF, Zhang G (2011) Osteopontin enhances the expression and activity of MMP-2 via the SDF-1/CXCR4 axis in hepatocellulat carcinoma cell lines. PLoS One 6(8): e23831.

Zhang W, Matrisian LM, Holmbeck K, Vick CC, Rosenthal EL (2006) Fibroblast-derived MT1-MMP promotes tumor progression in vitro and in vivo. BMC Cancer 6: 52.

This work is published under the standard license to publish agreement. After 12 months the work will become freely available and the license terms will switch to a Creative Commons AttributionNonCommercial-Share Alike 3.0 Unported License.

Supplementary Information accompanies this paper on British Journal of Cancer website (http://www.nature.com/bjc) 